\title{
Relative Toxicities of Inorganic Aluminum Complexes to Barley ${ }^{1}$
}

\author{
R. S. Cameron, G. S. P. Ritchie, AND A. D. Robson ${ }^{2}$
}

\begin{abstract}
The inorganic forms of $\mathrm{Al}$ in the soil solution that decrease plant growth in acid soils have not been clearly identified. Therefore, we examined the effects of $\mathrm{Al}$ and its complexes with $\mathrm{F}^{-}$and $\mathrm{SO}_{4}^{2-}$ on the root elongation of barley (Hordeum vulgare) in nutrient solutions containing $3333 \mu \mathrm{mol} \mathrm{Ca} \mathrm{L} ~^{-1}$ and $6 \mu \mathrm{mol} \mathrm{B} \mathrm{L}^{-1}$ at $\mathrm{pH}$ 4.5. The anions were chosen because of their presence in the soil solution at levels sufficient to complex Al. The toxicity of 0 to $100 \mu \mathrm{mol} \mathrm{Al} \mathrm{L^{-1 }}$ was studied in the presence of 0 to $10 \mu \mathrm{mol} \mathrm{F}^{-} \mathrm{L}^{-1}$ or $0-3300 \mu \mathrm{mol}$ $\mathrm{SO}_{4}^{2-} \mathrm{L}^{-1}$. The elongation of roots of barley seedlings was correlated with $\mathrm{Al}^{3+}$ concentrations but not with total soluble $\mathrm{Al}$ or $\mathrm{Al}$ complexed with $\mathrm{F}^{-}$and $\mathrm{SO}_{4}^{2-}$. This could be one of the reasons why measurements of labile Al using complexing agents have not always been successful at distinguishing between Al-toxic and nontoxic soils.
\end{abstract}

Additional Index Words: $\mathrm{pH}, \mathrm{Ca}, \mathrm{F}^{-}, \mathrm{SO}_{4}^{2-}$, nutrient solutions, soil acidity, alfalfa, Hordeum vulgare $\mathrm{L}$.

Cameron, R.C., G.S.P. Ritchie, and A.D. Robson. 1986. Relative toxicities of inorganic aluminum complexes to barley. Soil Sci. Soc. Am. J. 50:1231-1236.

$\mathrm{A}$ LUMINUM TOXICITY is a major factor limiting the growth of plants on acid soils (Foy, 1984). Despite considerable research, the identification of soils containing toxic levels of $\mathrm{Al}$ is still limited by our lack of understanding of which forms of soluble $\mathrm{Al}$ are responsible for decreased plant growth. The activity of total soluble aluminum, $\left(\mathrm{Al}_{\mathrm{T}}\right)$, has been shown to be more correlated with root elongation than total soluble $\mathrm{Al}$ concentration, $\left[\mathrm{Al}_{\mathrm{T}}\right]$ (Adams and Lund, 1966; Helyar, 1978). More recent studies with nutrient solutions have indicated that the "free" ion, $\mathrm{Al}^{3+}$, or the labile monomeric forms (i.e., $\mathrm{Al}^{3+}, \mathrm{Al}(\mathrm{OH})^{2+}$, $\mathrm{Al}(\mathrm{OH})_{2}^{+}$may be the major toxic species (Pavan and Bingham, 1982; Blamey et al., 1983).

The application of the above work to natural soil conditions has met with partial success when the activity of $\mathrm{Al}^{3+},\left(\mathrm{Al}^{3+}\right)$, is calculated from the total concentrations of all soluble ions and thermodynamic stability constants (e.g., Pavan et al., 1982; Sheppard and Floate, 1984). However, comparisons have not been so encouraging when toxic $\mathrm{Al}$ in soil is estimated by the speed with which it reacts with a complexing reagent (Adams and Hathcock, 1984). This measure of $\mathrm{Al}$ (labile $\mathrm{Al}$ ) is thought to consist of $\mathrm{Al}^{3+}$ and monomeric complexes with inorganic anions (James et al., 1983). The cause of such an anomaly could be due to the different toxicities of the inorganic forms of $\mathrm{Al}$ in solutions. Sulphate and $\mathrm{F}^{-}$are both capable of forming soluble complexes with $\mathrm{Al}$ at levels found in the soil solution (Ritchie, 1986).

The purpose of this work was to compare the toxic effect of $\mathrm{Al}^{3+}$ and its complexes with $\mathrm{F}^{-}$and $\mathrm{SO}_{4}^{2-}$.

\footnotetext{
'Contribution from Soil Science and Plant Nutrition, School of Agriculture, Univ. of Western Australia, Nedlands, WA Australia 6009 . This work was funded by the Australian Wool Corporation. Received 2 Jan. 1986.

${ }^{2}$ Former Research Officer, Lecturer and Professor of Agriculture (Soil Science), Soil Science and Plant Nutrition, School of Agriculture, Univ. of Western Australia, Nedlands, WA Australia 6009.
}

Initially, we examined the effect of $\mathrm{pH}$, ionic strength, and $\mathrm{Ca}^{2+}$ concentration on the elongation of the primary root of seedlings of barley (Hordeum vulgare L., cv. Beecher) and alfalfa (Medicago sativa L., cv. CUF 101) so that we could develop a suitable bioassay for examining the effects of $\mathrm{Al}$ on root growth.

\section{MATERIALS AND METHODS}

\section{Germination and Growth of Seedlings}

All seeds were sieved and germinated by immersion in an aerated, $200 \mu \mathrm{mol} \mathrm{CaSO}_{4} \cdot 2 \mathrm{H}_{2} \mathrm{O} \mathrm{L}^{-1}$ solution at $25 \pm 3^{\circ} \mathrm{C}$. Six seedlings were transplanted to each test solution when the radicles had emerged to approximately $3 \mathrm{~mm}$. The plants were suspended at the surface of the nutrient solution on cheesecloth stretched over a wire mesh template. This ensured that the root tips were always immersed in the solution.

The solutions contained only $\leqslant 1600 \mu \mathrm{mol} \mathrm{Ca}{ }^{2+} \mathrm{L}^{-1}$ and $6 \mu \mathrm{mol} \mathrm{B} \mathrm{L}{ }^{-1}$, as well as the experimental treatments. Calcium and $B$ are immobile in plants and are essential for root growth because they maintain the integrity of the root membrane (Haynes and Robbins, 1948). The seed provided an adequate source of all other nutrients over the short time period of the experiment. This prevented complications in the calculation of $\left(\mathrm{Al}^{3+}\right)$, which may have occurred if nutrients such as $\mathrm{H}_{2} \mathrm{PO}_{4}^{-}$had been added. The nutrient solutions were contained in 5-L plastic pots placed in root cooling tanks at $23 \pm 2{ }^{\circ} \mathrm{C}$. During plant growth, the solutions were aerated continuously and renewed daily to ensure constant levels of the ions present. The treatments were duplicated in all experiments.

\section{Development of Bioassay}

The purpose of the bioassay was to study the influence of external factors on $\mathrm{Al}$ toxicity and was not designed to monitor internal effects that may influence shoot growth only. The criterion for the development of the procedure was to establish a nutrient solution that contained the minimum nutrients required for adequate seedling growth over short time periods $(3 \mathrm{~d})$ but contained a minimum of ions that could affect the response of roots to $\mathrm{Al}$. No effort was made to use normal nutrient solutions or simulate the soil solution because both solutions are too complex to differentiate between the mechanisms under investigation.

Three factorial experiments were designed to study the effect of $\mathrm{pH}, \mathrm{Al}, \mathrm{Ca}^{2+}$, and ionic strength on primary root elongation of alfalfa and barley (Table 1). These plant species were chosen because of their sensitivity to Al toxicity (Russell, 1973).

Experiment 1 investigated the effect of $\mathrm{pH}$ on root elongation of alfalfa and barley seedlings and also the effect of Al at pH 4.0 only. Subsequently, alfalfa was chosen for further studies of the Al-H interaction (Exp. 2), whereas barley was selected to study the Al-Ca interaction (Exp. 3). Where necessary, $\mathrm{pH}$ was controlled by the addition of $17.3 \mathrm{mmol}$ $\mathrm{HCl} \mathrm{L^{-1 }}$ or $1.4 \mathrm{mmol} \mathrm{NaHCO}_{3} \mathrm{~L}^{-1}$. Ionic strength was maintained with $\mathrm{CaCl}_{2}$ and $\mathrm{KCl}$. Aluminum chloride was added to give a range of values of $\left(\mathrm{Al}^{3+}\right)$ from 0 to $16 \mu \mathrm{mol}$ $\mathbf{L}^{-1}$.

A preliminary experiment indicated that there was no effect of $\mathrm{Na}^{+}$or $\mathrm{K}^{+}$on root elongation at the levels used. Hence, in the subsequent experiments, $\mathrm{F}^{-}$and $\mathrm{SO}_{4}^{2-}$ were added as either the $\mathrm{Na}^{+}, \mathrm{K}^{+}$, or $\mathrm{Ca}^{2+}$ salts to ensure that 
Table 1. Experiment design and treatment levels for Exp. 1 to 3.

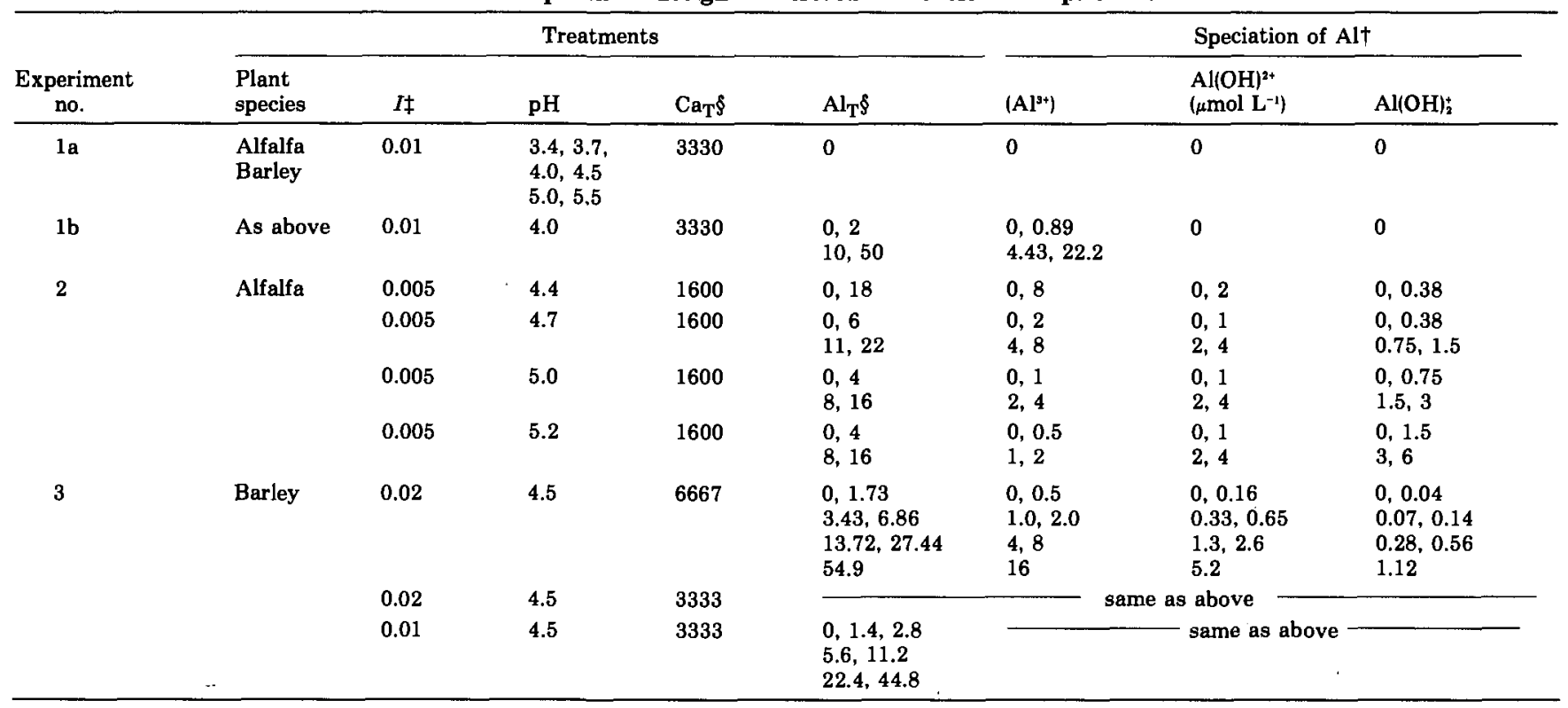

the toxicity of $\mathrm{Al}$ was related to the effects of $\mathrm{F}^{-}$and $\mathrm{SO}_{4}^{2-}$ only.

\section{Aluminum Toxicity in the Presence of Fluoride}

The effect of $\mathrm{F}^{-}$on the toxicity of Al to seedlings of barley was studied by measuring root elongation after $3 \mathrm{~d}$ growth in nutrient solutions (Exp. 4). The experiment was an incomplete factorial combination of 25 treatments with four levels of total $\mathrm{F}^{-}$concentrations, $\left[\mathrm{F}_{\mathrm{T}}\right]$, and 10 levels of total $\mathrm{Al}$ concentrations, $\left[\mathrm{Al}_{\mathrm{T}}\right]$, replicated in a completely random arrangement (Table 2). Aluminum and $\mathrm{F}^{-}$were added to the nutrient solutions as $\mathrm{AlCl}_{3}$ and $\mathrm{NaF}$, respectively. $\mathrm{A} \mathrm{Ca}$ concentration of $3333 \mu \mathrm{mol} \mathrm{L}^{-1}$, an ionic strength of 10000 $\mu \mathrm{mol} \mathrm{L}-1$ and a pH of 4.5 were used in all treatments. Ionic strength was maintained as in Exp. 1, 2, and 3.

\section{Aluminum Toxicity in the Presence of Sulphate}

An incomplete factorial design of 13 treatments was used to study the effect of $\mathrm{SO}_{4}^{2-}$ on the relationship between root elongation and Al toxicity to barley seedlings (Exp. 5). The experimental conditions were the same as for Exp. 4 except than no $\mathrm{F}^{-}$was present and $\mathrm{SO}_{4}^{2-}$ was added either as $\mathrm{CaSO}_{4} \cdot 2 \mathrm{H}_{2} \mathrm{O}$ and/or $\mathrm{KAl}\left(\mathrm{SO}_{4}\right)_{2}$. The treatment levels are given in Table 2.

\section{Calculation of Al Speciation}

The solution activities of free $\mathrm{Al}^{3+}$ and $\mathrm{Ca}^{2+}$ were calculated at each $\mathrm{pH}$ and ionic strength, I, from the thermodynamic stability constants given by Lindsay (1979) for the hydrolysis of $\mathrm{Al}^{3+}$ to $\mathrm{Al}(\mathrm{OH})^{2+}$ and $\mathrm{Al}(\mathrm{OH})_{2}^{+}$and from activity co-efficients calculated from thermodynamic stability constants for the formation of the species $\mathrm{CaSO}_{4}^{0}, \mathrm{AlOH}^{2+}$, $\mathrm{Al}(\mathrm{OH})_{2}^{+}, \mathrm{AlF}^{2+}, \mathrm{AlF}_{2}^{+}, \mathrm{AlF}_{3}^{0}, \mathrm{AlSO}_{4}^{+}$, and $\mathrm{Al}\left(\mathrm{SO}_{4}\right)_{2}^{-}$(Lindsay', 1979).

\section{RESULTS AND DISCUSSION Development of Bioassay}

In Exp. 1, increasing $\mathrm{H}^{+}$ion activity decreased the elongation of the primary root of both alfalfa and bar- ley (Fig. la and b). At pH 4, $\left[\mathrm{Al}_{\mathrm{T}}\right]>10 \mu \mathrm{mol} \mathrm{L}^{-1}$ decreased root growth of barley seedling from $29 \mathrm{~mm}$ to $\leqslant 11.3 \mathrm{~mm}$ (Fig. 1d). The growth of roots of alfalfa showed little response to $\mathrm{Al}$ (Fig. 1c), presumably because root growth had already been reduced to a minimum by the low $\mathrm{pH}$. However, at the higher $\mathrm{pH}$ values used in Exp. 2 (pH 4.4-5.2), root elongation of alfalfa seedlings was dependent on both $\mathrm{pH}$ and $\mathrm{Al}$ activity. In an attempt to combine these effects, root length was expressed as a percentage of root length in the absence of $\mathrm{Al}$ at the corresponding $\mathrm{pH}$ (i.e., relative root length, RRL) and plotted separately against the activities of $\mathrm{Al}^{3+}, \mathrm{Al}(\mathrm{OH})^{2+}$, and $\mathrm{Al}(\mathrm{OH})_{2}^{+}$.

Regardless of the Al species considered, there was still a wide range of RRL values at a constant activity: For example, RRL varied from 19 to $33 \%$ at a constant level of $2 \mu \mathrm{mol} \mathrm{L}^{-1}$ of $\mathrm{Al}^{3+}$ (Fig. 2a) and from 12.6 to $24 \%$ at $1 \mu \mathrm{mol} \mathrm{L}^{-1}$ of $\mathrm{Al}(\mathrm{OH})^{2+}$. Plots of root length vs. the individual $\mathrm{Al}$ species plus $\mathrm{H}^{+}$activity, $\left(\mathrm{H}^{+}\right)$, could not explain the response adequately either (data not shown). Assuming there is no effect on root elongation of $\mathrm{H}^{+}$at pH 5.2 , then the effect of $0.5 \mu \mathrm{mol}$ $\left(\mathrm{Al}^{3+}\right) \mathrm{L}^{-1}$ at $\mathrm{pH} 5.2$ is approximately equal to the effect of $40 \mu \mathrm{mol}\left(\mathrm{H}^{+}\right) \mathrm{L}^{-1}$ in the absence of $\mathrm{Al}$ (i.e., $\mathrm{pH}$ 4.4). Therefore, the depression in root growth caused by $1 \mu \mathrm{mol}\left(\mathrm{Al}^{3+}\right) \mathrm{L}^{-1}$ was approximately equivalent to the reduction caused by $80 \mu \mathrm{mol}\left(\mathrm{H}^{+}\right) \mathrm{L}^{-1}$. Similar relationships were estimated for the activities of $\mathrm{Al}(\mathrm{OH})^{2+}$ and $\mathrm{Al}_{\mathrm{T}}$. When the combined contribution of $\mathrm{Al}$ and $\mathrm{H}^{+}$was expressed in this manner, the response of root elongation to $\mathrm{pH}$ and $\mathrm{Al}$ was described by a single consistent relationship. This indicates that $\mathrm{H}^{+}$ions affected root growth of alfalfa seedlings in nutrient solutions in an independent but similar manner to Al. Even though the highest correlation was achieved by considering $\left(\mathrm{Al}^{3+}\right)$ alone (Fig. $2 b)$, the relationships with $\left(\mathrm{Al}_{\mathrm{T}}\right)$ and $\left(\mathrm{Al}(\mathrm{OH})_{2}^{+}\right)$were also quite adequate (Table 3 ). It is difficult to distinguish whether $\mathrm{Al}^{3+}$ or a hydrolyzed form is the major 
Table 2. Experiment design and treatment levels $\left(\mu \mathrm{mol} \mathrm{dm}^{-3}\right)$ for Exp. 4 and 5. Ionic strength $=0.01 \mathrm{~mol} \mathrm{~L}^{-1}, \mathrm{pH}^{-1} 4.5$, $\left[\mathrm{Ca}_{\mathrm{T}}\right]=3333 \mu \mathrm{mol} \mathrm{L} \mathbf{L}^{-1}$.

\begin{tabular}{|c|c|c|c|c|c|c|}
\hline \multirow{2}{*}{$\begin{array}{l}\text { Complexing } \\
\text { anion }\end{array}$} & \multirow[b]{2}{*}[\mathbf{C}_{\mathbf{T}}]{$\dagger$} & \multirow[b]{2}{*}{$\times\left[\mathrm{Al}_{\mathbf{T}}\right]$} & \multicolumn{4}{|c|}{ Speciation of Alt } \\
\hline & & & {$\left[\mathrm{Al}_{\mathrm{T}}{ }^{9+}\right]$} & $\mathrm{Al}(\mathrm{OH})^{2+}$ & $\mathrm{Al}(\mathrm{OH})_{2}^{+}$ & $\mathrm{Al}-\mathrm{C} \&$ \\
\hline \multicolumn{7}{|c|}{ Experiment 4} \\
\hline \multirow[t]{5}{*}{$\mathrm{F}$} & 0 & $\begin{array}{l}0,2,4 \\
6,8,100\end{array}$ & $\begin{array}{l}0,1.61,3.23,4.84 \\
6.45,80.6\end{array}$ & $\begin{array}{l}0,0.35,0.7 \\
1.05,1.4,17.7\end{array}$ & $\begin{array}{l}0,0.056,0.11 \\
0.17,0.22,2.82\end{array}$ & 0 \\
\hline & 2.5 & $\begin{array}{l}0,2,4,6,8, \\
10\end{array}$ & $\begin{array}{l}0.0 .34,1.50,2.99 \\
4.55,6.14\end{array}$ & $\begin{array}{l}0,0.075,0.33 \\
0.66,1.0,1.35\end{array}$ & $\begin{array}{l}0,0.012,0.052 \\
0.104,0.16,0.21\end{array}$ & $\begin{array}{l}0,1.57,2.12,2.25 \\
2.29,2.30\end{array}$ \\
\hline & 5 & $\begin{array}{l}0,4,6,8 \\
10,12\end{array}$ & $\begin{array}{l}0,0.54,1.53,2.89 \\
4.37,5.92\end{array}$ & $\begin{array}{l}0,0.11,0.33 \\
0.63,0.95,1.29\end{array}$ & $\begin{array}{l}0,0.017,0.052 \\
0.1,0.15,0.21\end{array}$ & $\begin{array}{l}0,3.33,4.10,4.38 \\
4.52,4.58\end{array}$ \\
\hline & 10 & $\begin{array}{l}0,4,8,10 \\
12,14,16\end{array}$ & $\begin{array}{l}0,0.07,0.82,1.69 \\
2.85,4.20,5.63\end{array}$ & $\begin{array}{l}0,0.015,0.18 \\
0.38,0.62 \\
0.91,1.22\end{array}$ & $\begin{array}{l}0,0.0023,0.029 \\
0.06,0.099 \\
0.145,0.194\end{array}$ & $\begin{array}{l}0,3.91,6.97,7.87 \\
8.43,8.75,9.00\end{array}$ \\
\hline & \multicolumn{5}{|c|}{ Experiment 5} & \\
\hline \multirow[t]{4}{*}{$\mathrm{SO}_{4}$} & 0 & $\begin{array}{l}0,1.26,3.14 \\
12.55\end{array}$ & $0,1,2.5,10$ & $\begin{array}{l}0,0.22,0.55 \\
2.2\end{array}$ & $\begin{array}{l}0,0.035,0.09 \\
0.35\end{array}$ & 0 \\
\hline & 1000 & $0,4.42,17.68$ & $0,2.5,10$ & $0,0.55,2.2$ & $0,0.09,0.35$ & $0,1.28,5.13$ \\
\hline & 2100 & $0,5.77,23.05$ & $0,2.5,10$ & \multirow{2}{*}{\multicolumn{2}{|c|}{$\begin{array}{l}\text { same as above } \\
\text { same as above }\end{array}$}} & $0,2.63,10.5$ \\
\hline & 3300 & $0,7.17,28.65$ & $0,2.5,10$ & & & $0,4.03,16.1$ \\
\hline
\end{tabular}

$\dagger$ Total concentration of complexing ion.

$\ddagger$ The corresponding concentration of Al species in each treatment, $\mu \mathrm{mol} \mathrm{L} \mathrm{L}^{-1}$

$\S\left(\mathrm{AlF}^{2+}+\mathrm{AlF}_{2}^{+}+\mathrm{AlF}_{3}^{0}\right)$ in Exp. 4 and $\left(\mathrm{AlSO}_{4}^{+}+\mathrm{Al}\left(\mathrm{SO}_{4}\right)^{-}\right)$in Exp. 5.

toxic species because they all vary in the same proportion when $\mathrm{Al}_{\mathrm{T}}$ is altered at a constant $\mathrm{pH}$.

At a constant $\mathrm{Ca}_{\mathrm{T}}$ of $3333 \mu \mathrm{mol} \mathrm{L}-1$, there was a negligible difference in the effect of $\left(\mathrm{Al}^{3+}\right)$ on root growth of barley seedlings at ionic strengths of 10000 and $20000 \mu \mathrm{mol} \mathrm{L}^{-1}$ (Fig. 3a). However, at a constant ionic strength of $20000 \mu \mathrm{mol} \mathrm{L}-1$ and $\left(\mathrm{Al}^{3+}\right)<8 \mu \mathrm{mol}$ $\mathrm{L}^{-1}$, root growth was greater at $\mathrm{Ca}_{\mathrm{T}}=6667 \mu \mathrm{mol} \mathrm{L}-1$ than at $3333 \mu \mathrm{mol} \mathrm{L}^{-1}$ (Fig. 3a). Therefore, the effect of $\mathrm{Al}$ was mitigated by $\mathrm{Ca}$ in the $\left(\mathrm{Al}^{3+} /\left(\mathrm{Ca}^{2+}\right)\right.$ range of $3.4 \times 10^{-4}$ to $8.0 \times 10^{-3}$. Other studies have also shown that $\mathrm{Ca}^{2+}$ can alleviate effects of $\mathrm{Al}$ on root growth of cotton (Gossypium hirsutum L.) (Adams and Lund, 1966) and soybeans [Glycine $\max$ (L.) Merr.] (Lund, 1970).

A consistent relationship between $\mathrm{Al}$ and root length was observed when $\left(\mathrm{Al}^{3+}\right)$ was expressed as a ratio with $\left(\mathrm{Ca}^{2+}\right)$ (Fig. 3b). A logarithm-logarithm transformation of the data was linear $(\log y=1.456-0.346$ $\left.\log x ; r^{2}=-0.947\right)$ between $\left(\mathrm{Al}^{3+}\right) /\left(\mathrm{Ca}^{2+}\right)$ ratios of $3.4 \times 10^{-4}$ and $8.0 \times 10^{-3}$. Outside this range, $\mathrm{Al}$ toxicity was independent of $\mathrm{Ca}$ concentration.

In experiments investigating $\mathrm{Al}$ toxicity, the experimental conditions must be selected so that the $\mathrm{H}^{+}$ effect is minimized and the $\left(\mathrm{Ca}^{2+}\right)$ effect is constant. Therefore, the following conditions were selected for the bioassays used to study the Al toxicity in the presence of $\mathrm{SO}_{4}^{2-}$ and $\mathrm{F}^{-}$ions.

An ionic strength of $10000 \mu \mathrm{mol} \mathrm{L} \mathrm{L}^{-1}$ and $\mathrm{a}\left[\mathrm{Ca}_{\mathrm{T}}\right]$ of $3333 \mu \mathrm{mol} \mathrm{L}{ }^{-1}$ were considered representative of levels found in soil solutions. A pH of 4.5 was selected as the highest $\mathrm{pH}$ that could be used before hydrolysis and precipitation of $\mathrm{Al}$ decreased $\left(\mathrm{Al}^{3+}\right)$ to negligible levels while still minimizing the $\mathrm{H}^{+}$effect on root growth. Barley was chosen as the indicator plant because at $\mathrm{pH} 4.5$ it was less sensitive to $\mathrm{H}^{+}$effects than alfalfa. Root growth of barley at pH 4.5 was $79 \%$ of the average growth at pHs 5.0 and 5.5 , whereas root elongation of alfalfa was only $63 \%$ of the average growth at higher pHs.
Table 3. Variance accounted for by linear regression of the $\log$ transformation of root length on $[\mathrm{Al}+\mathrm{H}]$ activity.

\begin{tabular}{ccc}
\hline$y$ & $x$ & Variance \\
\hline Root length & $\left(\mathrm{Al}^{3^{*}}\right)+\mathrm{H} / 80$ & 0.972 \\
& $\left(\mathrm{AlOH} \mathrm{H}^{2+}\right)+\mathrm{H} / 40$ & 0.910 \\
& $(\mathrm{Al}(\mathrm{OH})+\mathrm{H} / 27$ & 0.632 \\
& $\left(\mathrm{Al} \mathrm{T}_{\mathrm{T}}\right)+\mathrm{H} / 13$ & 0.914 \\
\hline
\end{tabular}

\section{Aluminum Toxicity in the Presence of Fluoride and Sulphate}

Increasing the concentration of $\mathrm{SO}_{4}^{2-}$ and $\mathrm{F}^{-}$in solution increased the elongation of roots of barley seedlings in the presence of Al but not in its absence (Fig. $4 \mathrm{a}$ and $5 \mathrm{a}$ ). For both $\mathrm{SO}_{4}^{2-}$ and $\mathrm{F}^{-}$, root length was not correlated with $\mathrm{Al}_{\mathrm{T}}$ (Fig. $4 \mathrm{a}$ and $5 \mathrm{a}$ ), $\mathrm{Al}-\mathrm{F}$ or $\mathrm{Al}-$ $\mathrm{SO}_{4}$ complexes, but was closely correlated with the concentration of $\mathrm{Al}^{3+}$ (Fig. $4 \mathrm{~b}$ and $5 \mathrm{~b}$ ). In these experiments $\mathrm{Al}^{3+}$ may be expressed as a concentration or an activity because ionic strength was constant. Thus, $\mathrm{Al}$ complexed with $\mathrm{SO}_{4}^{2-}$ and $\mathrm{F}^{-}$does not appear to be toxic to root elongation. There are insuffcient data points in Fig. 5 to establish whether the response of barley to $\mathrm{Al}$ in the presence of $\mathrm{SO}_{4}^{2-}$ is of a similar shape to that in the presence of $\mathrm{F}^{-}$(Fig. 4b). However, the points in Fig. $5 b$ fall on the same response curve as the data from the $\mathrm{F}^{-}$experiment if they are plotted on the same axes. The detoxifying effect of $\mathrm{F}^{-}$and $\mathrm{SO}_{4}^{2-}$ could be one of the reasons why measurements of labile $\mathrm{Al}$ using complexing agents have not always been successful at distinguishing between $\mathrm{Al}$ toxic and nontoxic soils.

Fluoride forms complexes with $\mathrm{Al}$ very readily and therefore was more effective in reducing the toxic effect of $\mathrm{Al}$ when compared with $\mathrm{SO}_{4}^{2-}$ at equal concentrations. Under the conditions of the experiment, $>90 \%$ of the total $\mathrm{F}^{-}$present was complexed with $\mathrm{Al}$, whereas $<0.5 \%$ of total $\mathrm{SO}_{4}^{2-}$ was forming ion pairs with Al. Therefore, the ability of these two anions to reduce Al toxicity in soils will depend on their concentration in the soil solution. 

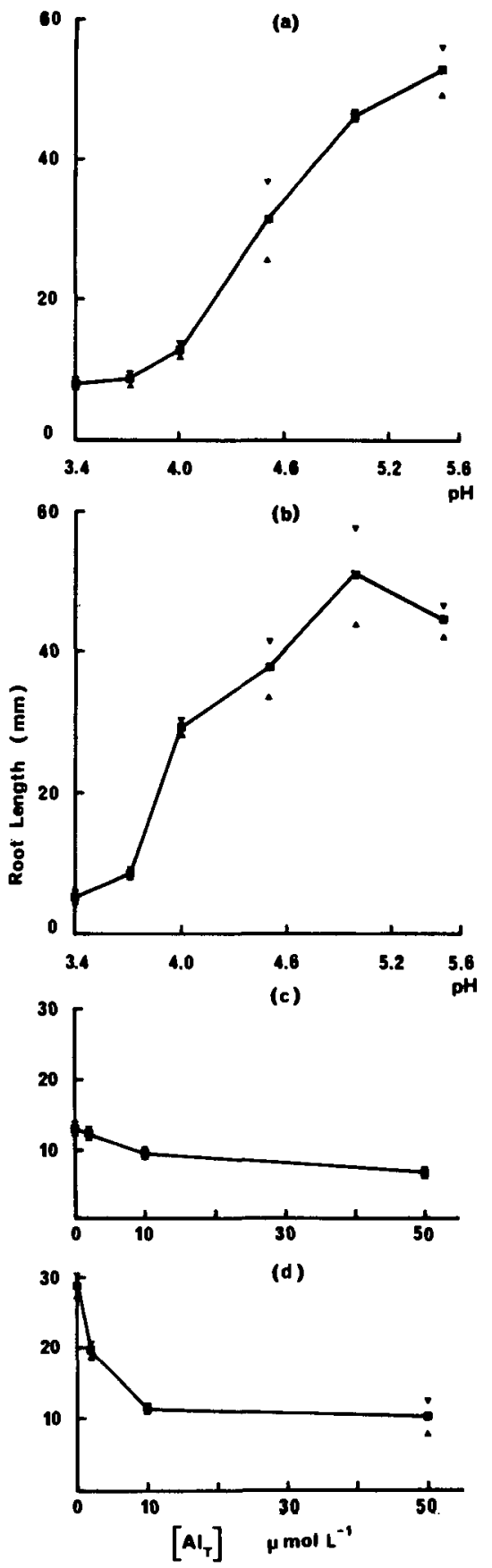

Fig. 1. The effect of pH [(a) and (b)] and [Al] at pH $4[$ (c) and (d)] on the root length of alfalfa $[(a)$ and (c)] and barley $[(b)$ and (d)].

The average level of $\mathrm{F}^{-}$in soil solutions appears to be about $10 \mu M$ (Larsen and Widdowson, 1971; David and Driscoll, 1984) even though total $\mathrm{F}^{-}$levels in a soil may be as high as $300 \mu \mathrm{g} \mathrm{g}^{-1}$ (Adriano and Doner, 1982). The low levels of soluble $\mathrm{F}^{-}$suggest that it will only be important in reducing $\mathrm{Al}$ toxicity in soils which contain soluble Al levels that are marginally toxic. Even though soluble $\mathrm{SO}_{4}^{2-}$ levels are much higher than $\mathrm{F}^{-}$in acid soils $\left(100-1000 \mu \mathrm{mol} \mathrm{L}^{-1}\right), \mathrm{SO}_{4}^{2-}$ will be less effective at reducing $\mathrm{Al}$ toxicity because of its low complexing capacity (Ritchie, 1986).

There is also evidence that $\mathrm{Al}$ complexed with phosphate and organic ligands is not toxic to plants (Bar-
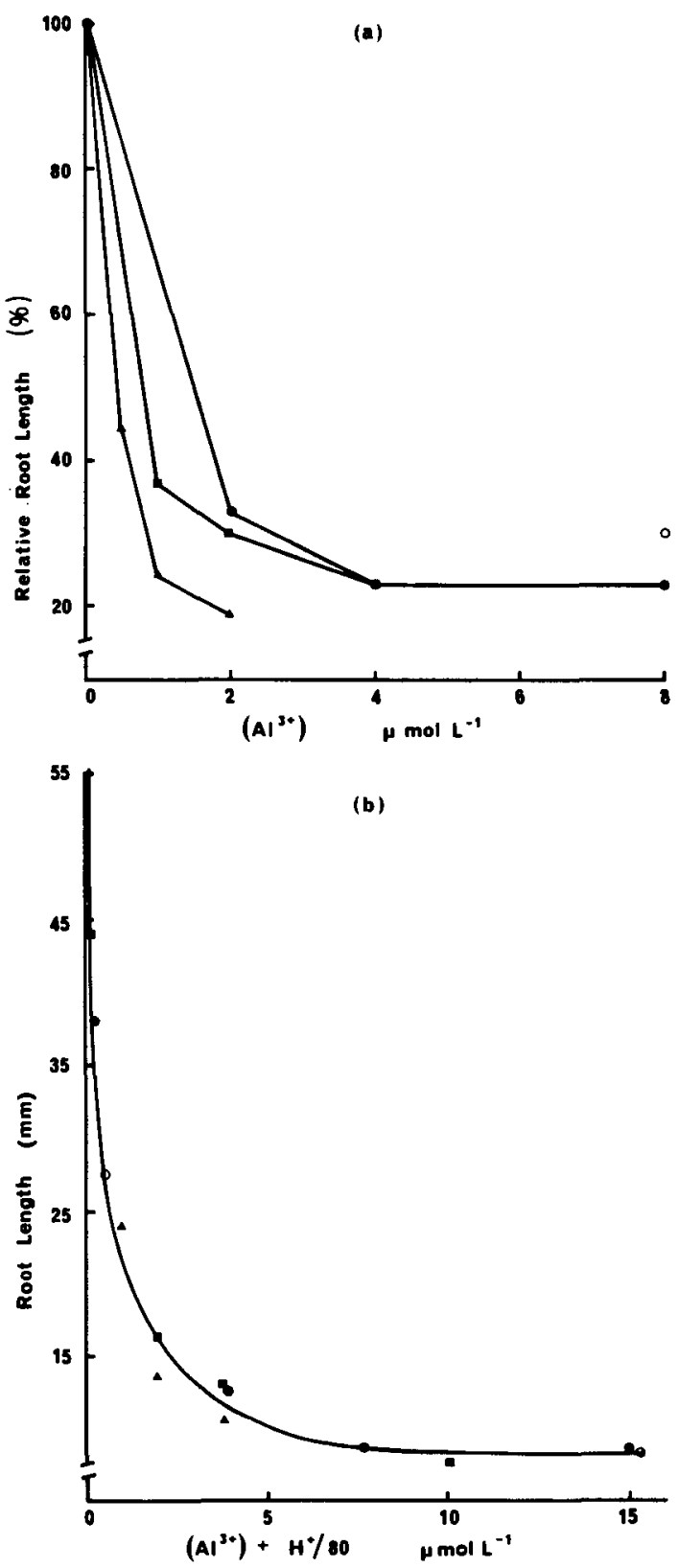

Fig. 2. The variation in relative root length of alfalfa with (a) $\left(\mathrm{Al}^{3+}\right)$ and $(\mathrm{b})\left(\mathrm{Al}^{3+}\right)+\left(\mathrm{H}^{+} / 80\right)$ at $\mathrm{pH} 4.4(0) 4.7(\bullet), 5.0(\square)$, and 5.2 (A).

tlett and Riego, 1972; Blamey et al., 1983; Hue et al., 1986). The phosphate complex appears to be polymeric and did not react with a complexing reagent during the short time period that is used to assess labile Al (Blamey et al., 1983). The behavior of Alorganic complexes is less clear. Turner and Sulaiman (1971) and Hoyt and Turner (1975) found that complexing agents (aluminon and hydroxyquinoline) reacted very quickly $(<1 \mathrm{~min}$ ) with salicylate and citrate complexes of Al. On the other hand, complexes with larger organic ligands (e.g., humic or fulvic acids) may not be so reactive (James et al., 1983).

All anions discussed could be responsible for our inability to distinguish between Al toxic and nontoxic soils. However, we have yet to establish their impor- 


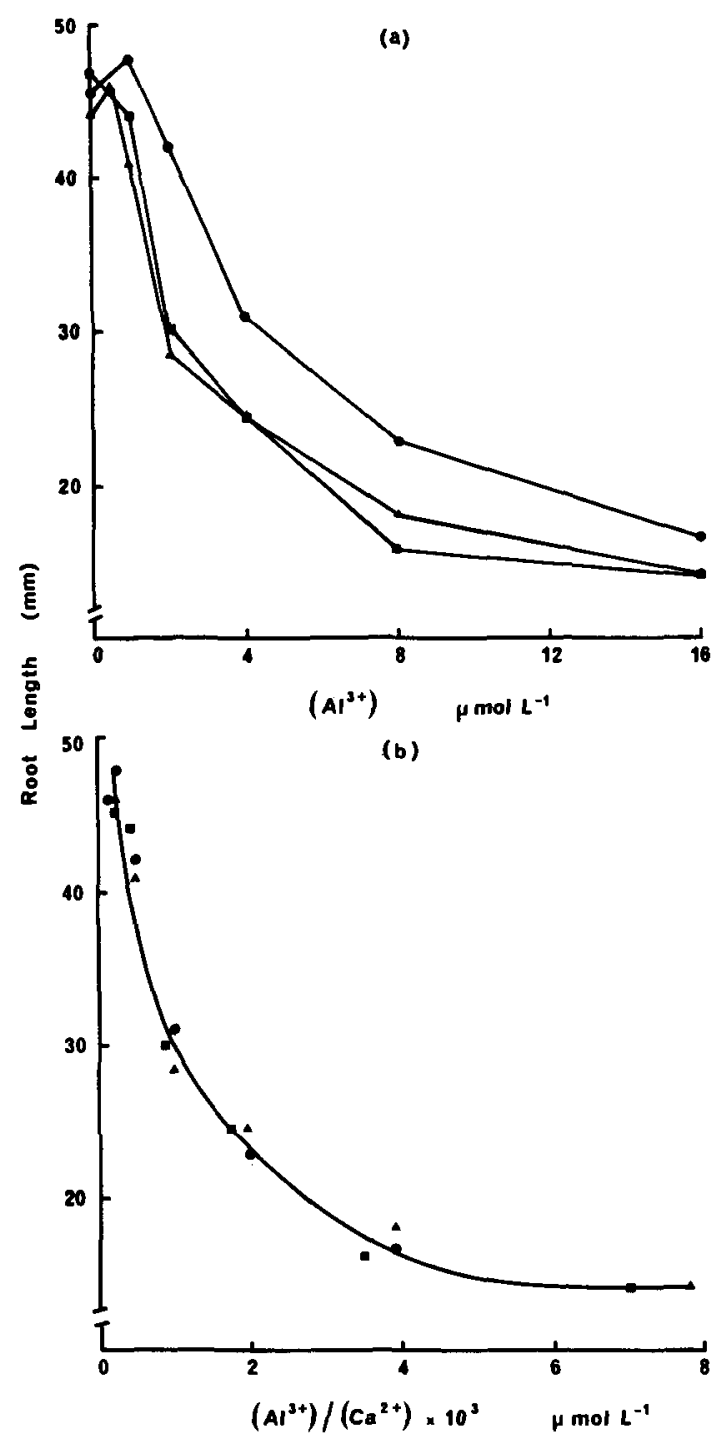

Fig. 3. The variation in root length of barley with (a) $\left(\mathrm{Al}^{3+}\right)$ and (b) $\left(\mathrm{Al}^{3+}\right) /\left(\mathrm{Ca}^{2+}\right)$ at I $=20000 \mu \mathrm{mol} \mathrm{L}{ }^{-1},[\mathrm{Ca}]=6667 \mu \mathrm{mol} \mathrm{L} \mathrm{L}^{-1}(\mathrm{~b})$ and $[\mathrm{Ca}]=3333 \mu \mathrm{mol} \mathrm{L}^{-1}(\Delta)$, and $I=10000 \mu \mathrm{mol} \mathrm{L} \mathrm{L}^{-1}$ and [Ca] $=3333 \mu \mathrm{mol} \mathrm{L}^{-1}(\mathbf{a})$.

tance relative to each other and to other factors that may influence Al toxicity. Equally, the specificity of methods used to measure labile Al requires further clarification.

\section{REFERENCES}

Adams, F., and P.J. Hathcock. 1984. Aluminum toxicity and calcium deficiency in acid subsoil horizons of two Coastal Plains Soil Series. Soil Sci. Soc. Am. J. 48:1305-1309.

Adams, F., and Z.F. Lund. 1966. Effect of chemical activity of soil solution aluminium on cotton root penetration of acid subsoils. Soil Sci. 101:193-198.

Adriano, D.C., and H.E. Doner. 1982. Bromine, chlorine and fluorine. In A.L. Page et al. (ed.) Methods of soil analysis, Part 2. Agronomy 9:449-484.

Bartlett, R.J., and D.C. Riego. 1972. Effect of chelation on the toxicity of aluminum. Plant Soil 37:419-423.

Blamey, F.P.C., Edwards, D.G., and C.J. Asher. 1983. Effects of aluminum, $\mathrm{OH}: \mathrm{Al}$ and $\mathrm{P}: \mathrm{Al}$ molar ratios, and ionic strength on soybean root elongation in solution culture. Soil Sci. 136:197207.

David, M.B., and C.T. Driscoll. 1984. Aluminum speciation and equilibria in soil solutions of a haplorthod in the Adirondack mountains (New York, U.S.A.). Geoderma 33:297-318.

Foy, C.D. 1984. Physiological effects of hydrogen, aluminium and

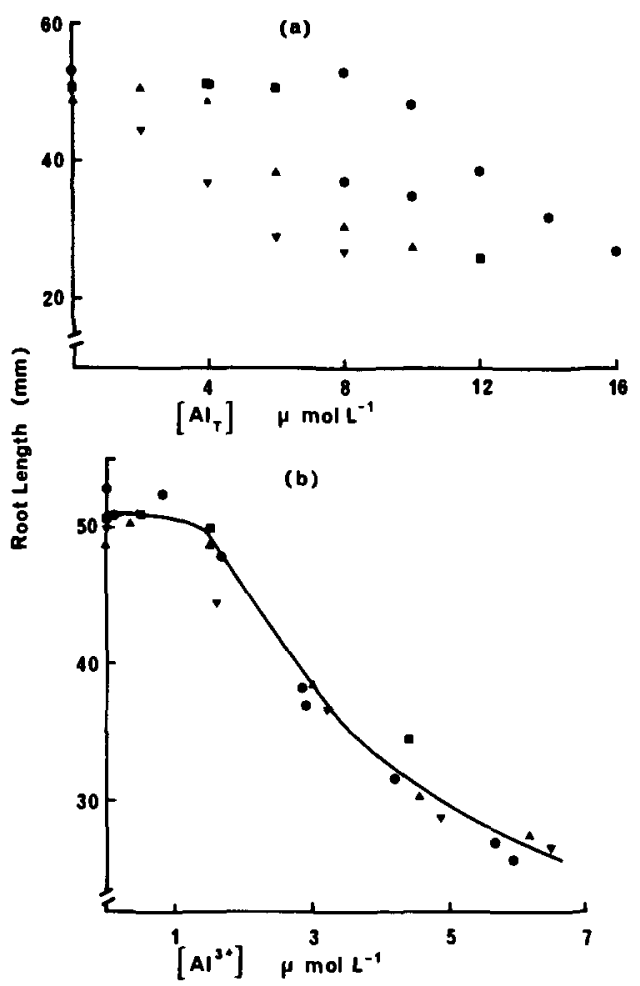

Fig. 4. The variation in root length of barley with (a) $\left[\mathrm{Al}_{\mathrm{T}}\right]$ and (b) $\left[\mathrm{Al}^{3+}\right]$ in the presence of $0(\nabla), 2.5(\Delta), 5(\mathrm{D})$, and $10(\bullet) \mu \mathrm{mol}$ $\mathbf{F}^{-} \mathbf{L}^{-1}$.

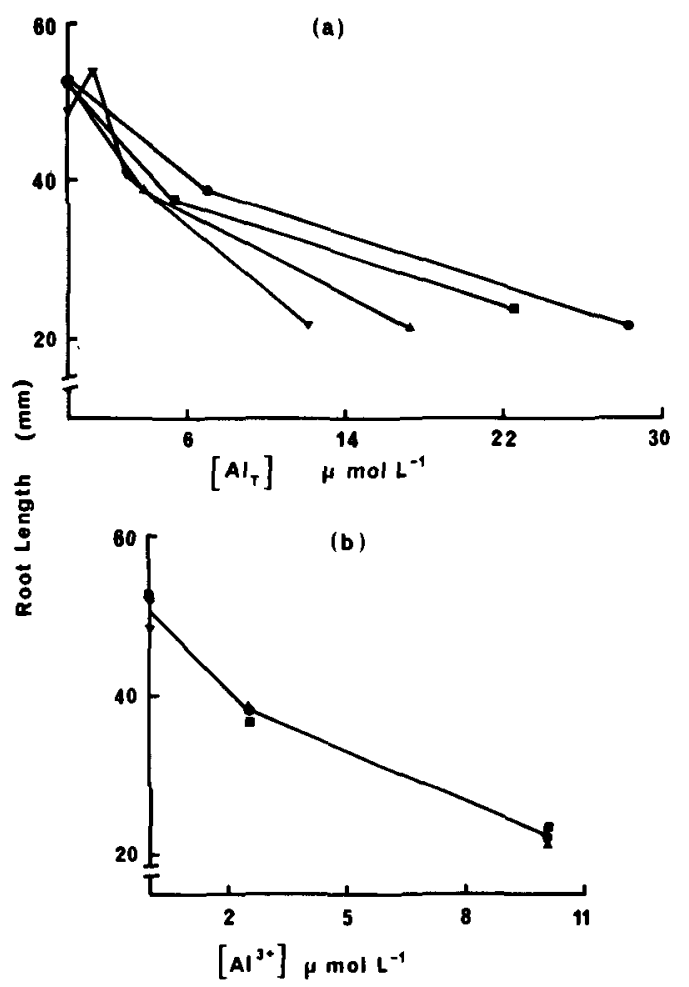

Fig. 5. The variation in root length of barley with (a) $\left.[A]_{T}\right]$ and $(b)$ $\left[\mathrm{Al}^{3+}\right]$ in the presence of $0(\nabla), 1000(\triangle), 2100(\mathrm{a})$, and $3300(\bullet)$ $\mu \mathrm{mol} \mathrm{SO}_{4}^{2-} \mathbf{L}^{-1}$.

manganese toxicities in acid soils. In F. Adams (ed.) Soil acidity and liming. Agronomy 12:57-97.

Haynes, J.L., and W.R. Robbins. 1948. Calcium and boron as essential factors in the root environment. J. Am. Soc. Agron. 40:795- 
803.

Helyar, K.R. 1978. Effects of aluminium and manganese toxicities on legume growth. p. 207-231. In C.S. Andrew and E.J. Kamprath (ed.) Mineral nutrition of legumes in tropical and sub-tropical soils. CSIRO, Melbourne, Australia.

Hoyt, P.B., and R.C. Turner. 1975. Effects of organic materials added to very acid soils on $\mathrm{pH}$, aluminium, exchangeable $\mathrm{NH}_{4}$ and crop yields. Soil Sci. 119:227-237.

Hue, N.V., G.R. Craddock, and F. Adams. 1986. Effects of organic acids on aluminium toxicity in subsoils. Soil Sci. Soc. Am. J. 50:28-34.

James, B.R., Clark, C.J., and S.J. Riha. 1983. An 8-hydroxyquinoline method for labile and total aluminum in soil extracts. Soil Sci. Am. J. 47:893-897.

Larsen, S., and A.E. Widdowson. 1971. Soil Fluorine. J. Soil Sci. $22: 210-221$.

Lindsay, W.L. 1979. Chemical equilibria in soils. John Wiley, New York.

Lund, Z.F. 1970. The effect of calcium and its relation to several cations in soybean root growth. Soil Sci. Soc. Am. Proc. 34:4569.

Pavan, M.A., and F.T. Bingham. 1982. Toxicity of aluminum to coffee seedlings grown in nutrient solution. Soil Sci. Soc. Am. J. 46:993-997.

Pavan, M.A., Bingham, F.T, and P.F. Pratt. 1982. Toxicity of aluminum to coffee in utisols and oxisols amended with $\mathrm{CaCO}_{3}$, $\mathrm{MgCO}_{3}$, and $\mathrm{CaSO}_{4} \cdot 2 \mathrm{H}_{2} \mathrm{O}$. Soil Sci. Soc. Am. J. 46:1201-1207.

Ritchie, G.S.P. 1986. The chemical behavior of aluminium, hydrogen and manganese in acid soils. In A.D. Robson et al. (ed.) Soil acidity and plant growth. Academic Press, Sydney. (in press).

Russell, E.W. 1973. Soil conditions and plant growth, 10th ed. Longman, London.

Sheppard, L.J., and M.J.S. Floate. 1984. The effects of soluble-Al on root growth and radicle elongation. Plant Soil 80:301-306.

Turner, R.C., and W. Sulaiman. 1971. Kinetics of reactions of 8quinolinol and acetate with hydroxyaluminum species in aqueous solutions. 1. Polynuclear hydroxyaluminum cations. Can. J. Chem. 49:1683-1687. 